\title{
RUSSIAN FINANCIAL MARKETS IN JANUARY 2016
}

\author{
E.Gorbatikov, E.Khudko
}

The price of Brent crude was up more than $11 \%$ in the period under review (between 27 January 2016 and 25 February 2016) after striking a low of \$28.2 a barrel during the previous period under review (between 23 December 2015 and 26 January 2016). The increase took place as the MICEX Index was up $5.8 \%$ and almost all the sector indexes hiked. Blue-chip stocks were also driven by overall upward dynamics. In terms of ROE, Sberbank was ranked first among Russia's top blue-chip stocks, and its share of total market turnover at the Moscow Exchange swelled by more than one third. Investors continued to withdraw from Russia-focused mutual funds, pulling out $\$ 336.3 m$ year to date.

The domestic corporate bond market continued to face the downtrend, and primary market players' activity stayed low. Nevertheless, the key indicators such as the corporate bond index and bond yields, as well as investors' activity in the secondary market, were driven by positive dynamics. The challenging issue of Russian companies defaulting on debt obligations due to their bond holders continued to be the key troublesome factor.

\section{The dynamics of the Russian stock market's key structural indices}

Both the MICEX Index and the price of oil were driven by upward dynamics during the period under review (between 27 January 2016 and 25 February 2016) after falling for three months in a row. The MOEX Index surged $5.8 \%$ during the same period, striking 1800 points $^{1}$. However, the index lost $1.6 \%$ during the past three months. Brent futures prices never fell below $\$ 30$ a barrel during the period under review, showing an EOM increase of $11.2 \%$; no such EOM growth was seen since April 2015. At the same time, crude oil prices were extremely volatile, varying more than $3 \%$ in half of 22 days of the period under review.

The fall during the previous period under review gave way to a synchronous raise of almost all Russia's top blue-chip stocks. Nearly all Russia's highly liquid companies ${ }^{2}$ were in the green as of the end of the month, except Magnit (down 4.1\%), which was ranked first in terms of ROE among the top blue-chip stocks during the previous period under review, and Norilsk Nickel (down $1.5 \%$ ) whose stock continued to fall

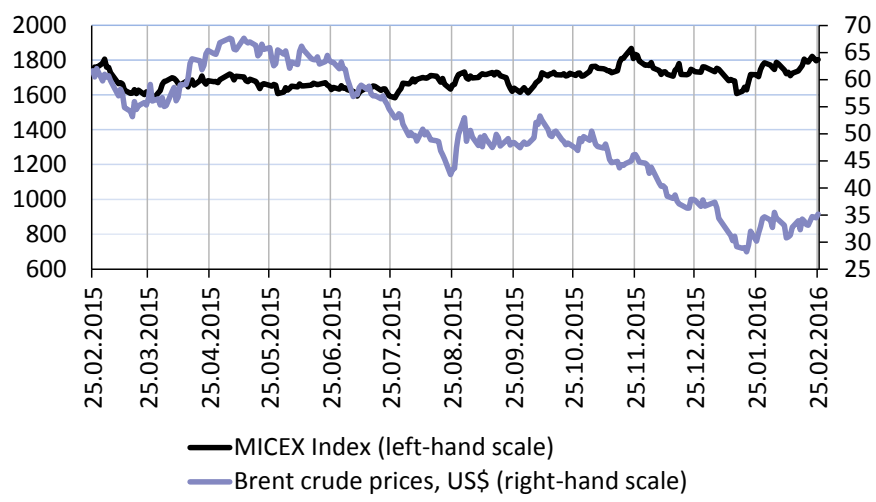

Sources: Quote RBC, Finam.

Fig. 1. The dynamics of the MICEX Index and Brent futures prices in the period between 25 February 2015 and 25 February 2016

1 All the prices hereinafter refer to MOEX closing prices.

2 Highly liquid companies hereinafter refer to companies with an average daily stock trade volume above $\mathrm{Rb} 1 \mathrm{bn}$ during the period under review. 


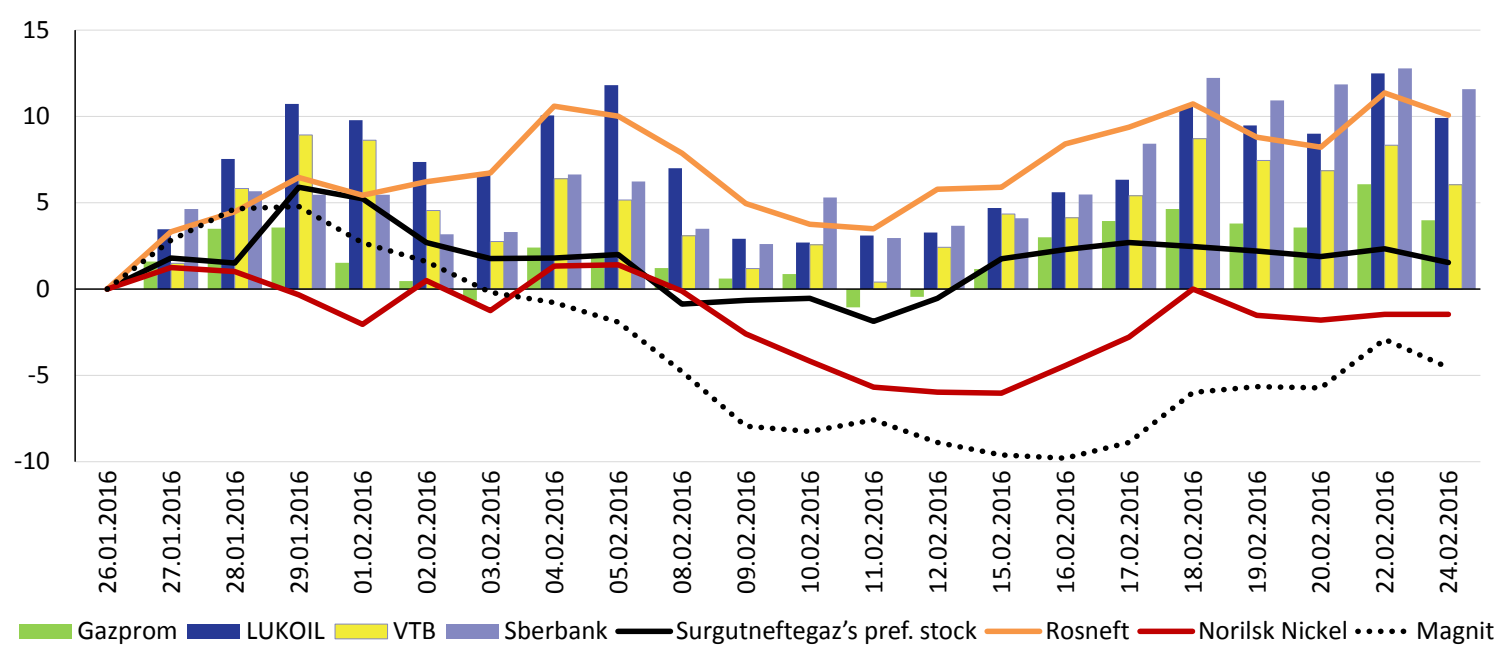

Fig. 2. Quotation growth rates for highly liquid Russian stocks on the Moscow Exchange in the period between 27 January 2016 and 25 February 2016

for the fourth straight month. In terms of end-of-month growth, the top-3 companies included Rosneft (up 9.2\%), Lukoil (up 10.0\%) and Sberbank (up 13.7\%). Rosneft was alone among the top blue-chip stocks to see growth for the second straight month. The growth in the period under review helped Sberbank nearly to recover from the 2-month decline.

In terms of annual ROE, Sberbank was ranked first among Russia's top blue-chip stocks for the third straight month, up more than $40 \%$ from February 2015. The rest of

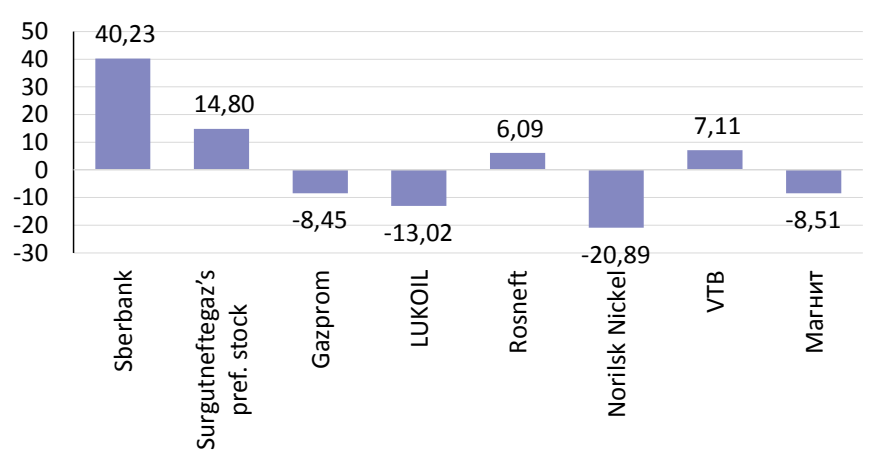

Sources: Quote RBC, authors' calculations.

Fig. 3. Growth rates in the value of highly liquid Russian stocks at Moscow Exchange in the period between 25 February 2015 and 25 February 2016

the blue-chip stocks saw no changes from the previous month. The stocks of Surgutneftegaz, VTB and Rosneft appreciated at year's end (in the period between 25 February 2015 and 25 February 2016), whereas the stocks of Magnit, Gazprom, Lukoil and Norilsk Nickel depreciated. Lukoil faced growth during the period under review, whereas Norilsk Nickel lost 20.9\%, replacing Lukoil as the top loss making highly liquid company at year-end.

Nearly all the sectoral indices were driven by upward dynamics at the end of the month, except the Machinery Manufacturing Index (down 1.9\%) and the Chemicals Index (a token decline of $0.3 \%$, however, it was alone among the other indices to fall for the second straight month). The Financials Index nearly recovered from the losses sustained a month earlier (up 6.0\%, Sberbank and VTB contributed most to the growth). The Metals \& Mining Index (up 7.2\%) was ranked fist in terms of value, mostly due to a nearly $15 \%$ growth of OJSC Novo Lipetsk Steel shares. Furthermore, the Oil \& Gas and Electric Utilities Indices increased more than 5\% a month.

The Moscow Exchange (MOEX) total trading turnover within 22 trading days of the period under review stood at $\mathrm{Rb} 764 \mathrm{bn}$, or $\mathrm{Rb} 34.7 \mathrm{bn}$ a day, up 


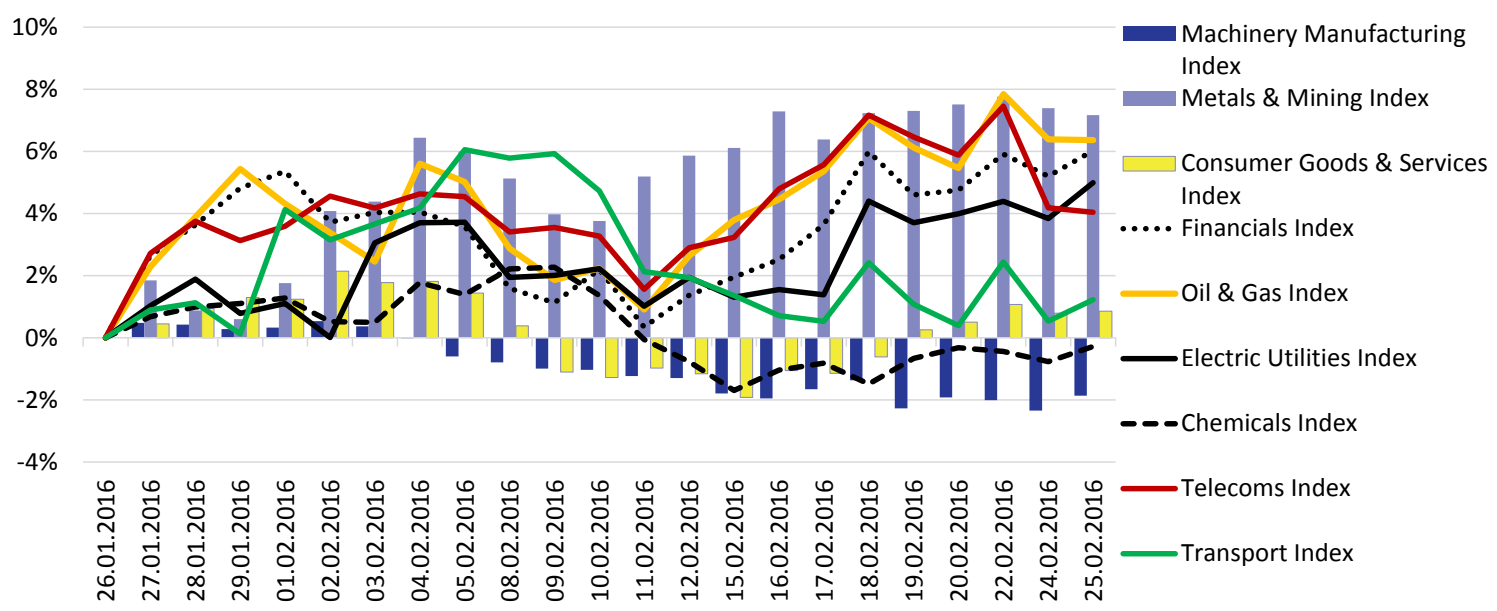

Sources: Quote RBC, the author's calculations.

Fig. 4. Growth rates in various sector indices at Moscow Exchange in the period between 27 January 2016 and 25 February 2016

$13.9 \%$ over the previous period under review, up 5.7\% over the past three month average as well as the yearly average. On the other hand, the MOEX trading turnover in the same period last year was higher by $25.5 \%$.

In terms of a share of the MOEX total trading turnover, Sberbank was ranked first, its share was up more than $3 \%$ to $33.5 \%$, Gazprom was second $(12.0 \%$ against $13.0 \%$ a month earlier) and Lukoil was third $(8.0 \%)$. The stocks of the above mentioned companies, as well as Magnit, Norilsk Nickel, Surgutneftegaz, VTB and Rosneft, were traded at more than Rb 1 bn a day. Emphasis should be placed on a growth in the trading turnover of Novatek and ALROSA stocks, each accounting for more than $2 \%$ of the MOEX trading turnover. Thus the three companies with the biggest stock turnover accounted for more than $50 \%$ of the transactions at MOEX (53.6\% against $50.8 \%$ a month earlier), whereas the next five companies made up $23.0 \%(26.8 \%$ a month earlier). The foregoing eight blue-chip stocks accounted for $76.6 \%$ of

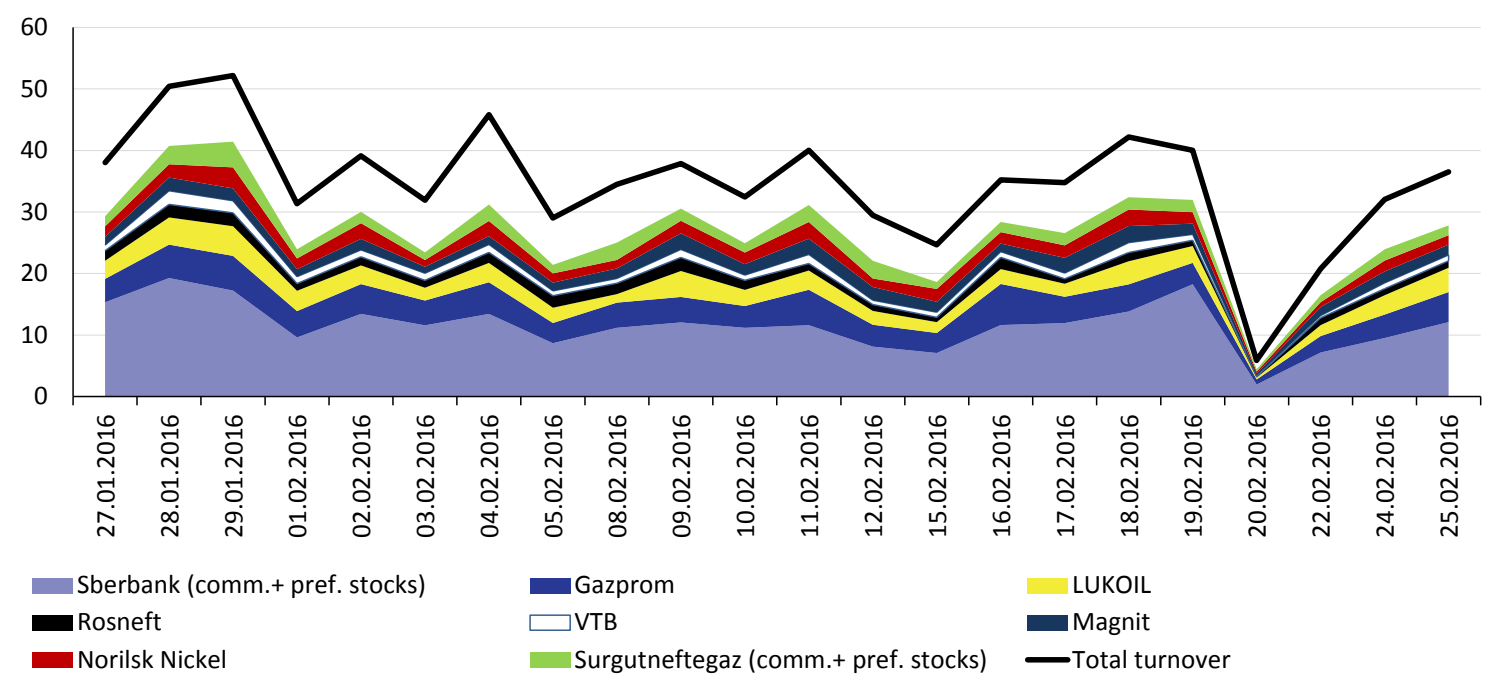

Sources: RBK Quote, author's calculations.

Fig. 5. The structure of trading turnover at MOEX in the period between 27 January 2016 and 25 February 2016 
all the transactions at MOEX, $1 \%$ less than a month earlier but still more than $3 / 4$ of the total volume.

According to the data released by the Emerging Portfolio Fund Research (EPFR), investors continued to withdraw from Russia-focused mutual funds. Nominal inflow of investors (up $\$ 1.1 \mathrm{~m}$ ) was seen only in a single week (28 January through 3 February 2016) of the five trading weeks between 21 January and 24 February, and investors pulled out a total of $\$ 176.5 \mathrm{~m}$, and the year-to-date outflow was $\$ 336.3 \mathrm{~m}$. Mutual funds that invest only in Russian securities saw a small inflow of investors during the past four

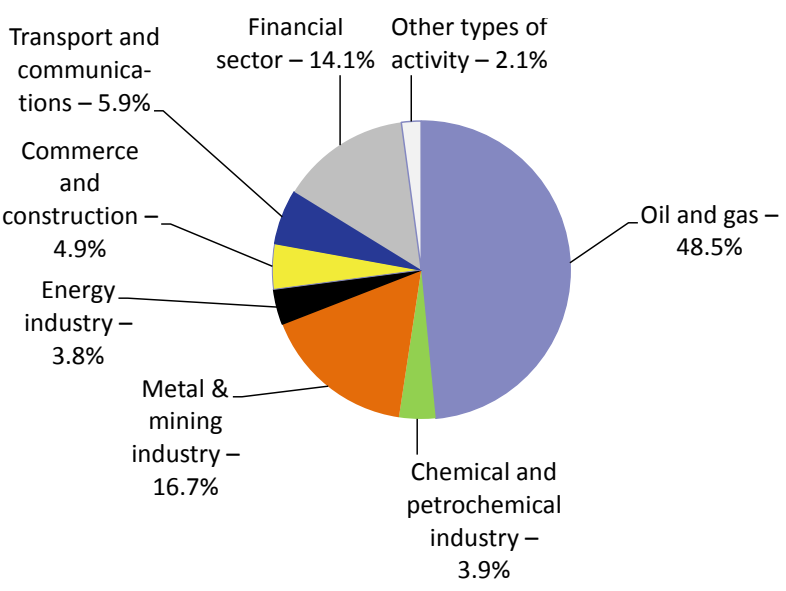

Sources: The Moscow Exchange official website, author's calculations.

Fig. 6. Stock market's capitalization structure by type of economic activities as of 25 February 2016 weeks (up $\$ 25.8 \mathrm{~m}$ ), but the inflow cannot beat the weekly outflow (down $\$ 33.8 \mathrm{~m}$ ) between 21-27 January 2016 .

MICEX capitalization was up more than $6 \%$ to $\mathrm{Rb} 29.6$ trillion $(36.8 \%$ of $\left.G^{1}{ }^{1}\right)$. The share of industries of the MOEX capitalization changed insignificantly. The share of the oil \& gas and finance industries increased slightly (up $0.4 \%$ and $0.6 \%$, respectively, over the previous month), whereas the commerce and construction industries saw their share shrink $0.4 \%$, and the share of the chemical industry decreased by $0.3 \%$.

\section{Coroprate bond market}

The volume of Russia's domestic corporate bond market (as measured by the par value of outstanding rouble-denominated securities including nonresidents' securities) declined in February for the first time in two years, its February month-end value stood at $\mathrm{Rb} 7.819 .5 \mathrm{bn}$, down $1.1 \%$ from the previous month-end value ${ }^{2}$. The elapsed period saw no changes in the number of outstanding bond issuances (1189 rouble-denominated corporate bond issuances were registered versus 1188 issuances as of the end of January), whereas the number of issuers in the debt segment increased slightly (421 issuers versus 410 companies a month earlier). Bonds issued by oil\&gas and banking issuers made up nearly half of the market volume. Nineteen Russian dollar-denominated bond issuances (worth a total of $\$ 6.5 \mathrm{bn}$ ) and a single JPY-denominated bond issuance (note that the issuer has entered into liquidation) remained outstanding in the market.

Investors' activity in the secondary corporate bond market increased markedly. For instance, in the period between 26 January and 24 February MOEX trading volume in rouble-denominated securities amounted to $\mathrm{Rb} 121.8 \mathrm{bn}$ (compared with the trading volume worth $\mathrm{Rb} 83.6 \mathrm{bn}$ in the period between 22 December and 25 January 2016). The number of transactions with securities continued to stay highest in the last 12 months, 34,700 at February month-end $\left(34,100\right.$ MOEX transactions were closed in the prior period) ${ }^{3}$.

1 The data for Russia's 2015 GDP are presented in http://www.gks.ru/

2 Based on the data released by Rusbonds Information Agency.

3 Based on the data released by Finam Investment Company. 
The Russian Corporate Bond Market Index (IFX-Cbonds) continued to face moderate uptrend. Late in February the Index was up 4.5 points (or up $1.0 \%$ ) over the prior-month-end value. The average weighted yield of corporate bonds attempted a reversal to downward dynamics: it declined from $11.71 \%$ in late January to $11.57 \%$ by late February (Fig. 7) ${ }^{1}$, although the central bank said the country faces the risk of inflation ramp-up. The

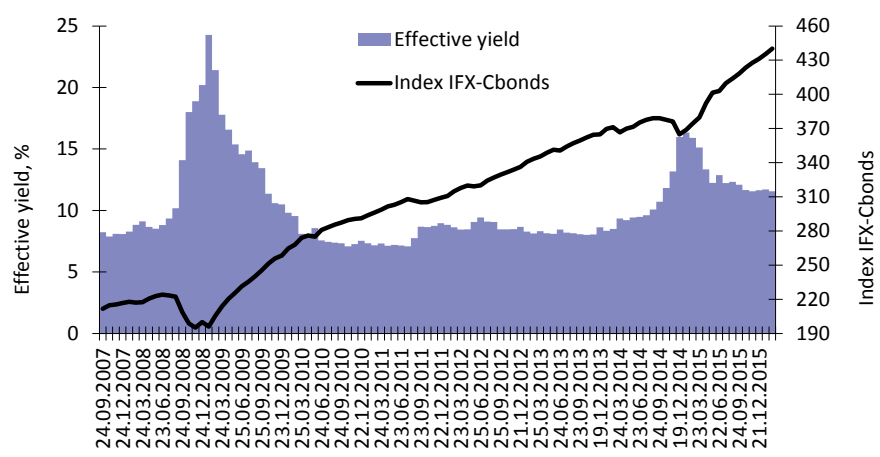

Source: Cbonds Information Agency.

Fig. 7. The dynamics of the Russian corporate bond market index and the average weighted yield corporate bond portfolio duration declined further, reaching 292 days at February month-end, which is 28 days less than the prior-month-end value.

Late in January/February 2016 the Russian financial market was driven by adverse external factors. In particular, investors were focused on mineral markets. The price of oil during the period under review remained very low, and international organizations (the World Bank, IEA, international rating agencies ${ }^{2}$ ) downgraded their forecast for the average oil price for 2016, adding to a negative outlook. The oil factor pushed down the rouble's exchange rate and the yield of securities, although experts noted this relationship was weakening. Furthermore, prices of non-ferrous metals were anticipated to drop as well. At the same time, the price of gold was driven up in February, reaching local highs in the past two years, owing to strong volatility in global financial markets. Moody's and Fitch rating agencies, Morgan Stanley, the European Commission followed the IMF which forecasted that Russia's GDP will decline further in 2016.

During the period under review the most liquid segment of the domestic corporate bond market was affected by overall moderate downtrend in the yield of securities. The bond issuances of LLC EvrazHolding Finance and the State Corporation "Bank for Development and Foreign Economic Affairs (Vnesheconombank)" saw the deepest cut in the interest rate (down more than 1.5 p.p.), whereas the securities of OJSC Rosbank and OJSC Norilsk Nickel $^{3}$ saw a similar growth in the yield. Overall, the interest rate of highly liquid securities in the financial, technological and energy segments of the market were driven by a marked downtrend (by an average of $0.3-0.4$ p.p.). In terms of yield, the securities of production companies were less affected by the overall downtrend, down slightly more than 0.1 p.p.. Besides oil companies, steel producers are facing challenges that are associated not only with the price factor (in particular, the World Bank cut its forecasts for nonferrous metals prices for 2016) but also with the decisions of the European Commission to introduce provisional anti-dumping duties against Russia's flat rolled steel. The securities of production, financial and technology companies saw higher investment demand during the period under review, whereas the energy segment was facing an extremely low trading volume.

1 Based on the data released by Cbonds Information Agency.

2 Based on the data released by Cbonds Information Agency and Finam Investment Company.

3 Based on the data released by Finam Investment Company. 
Issuers' activity in terms of seeking new fundraising during the period under review was relatively weak. For instance, in the period between 26 January and 24 February, 11 issuers registered 24 corporate bond issuances with an aggregate par value of $\mathrm{Rb} 84.5 \mathrm{bn}$ (by comparison, a volume of nearly $\mathrm{Rb} 200 \mathrm{bn}$ was registered in the previous 2-month period, although prior to that period the amount of monthly registered bond issuances ranged between mere $\mathrm{Rb} 50$ and $80 \mathrm{bn})^{1}$. The following issuers registered the biggest volume of bond issuances: OJSC Irkutskenergo (Rb 20bn), LLC RSG-Finance ( $\mathrm{Rb} 17.5 \mathrm{bn}$ ) and JSC Gazprombank (Rb 15bn). A few other bond programmes are expected to launch soon; in particular, EvrazHolding Finance approved a 15-year exchange-traded bond programme worth up to $\mathrm{Rb} 200 \mathrm{bn}$, Rusfinance Bank approved a similar programme worth $\mathrm{Rb} 50 \mathrm{bn}$; SUEK-Finance is set to issue exchange-traded bonds worth $\mathrm{Rb} 40 \mathrm{bn}$, International Invest Bank is preparing a 30-year bond programme worth up to $\mathrm{Rb} 100 \mathrm{bn}$.

As opposed to the secondary market, investors' activity in the primary market was very weak. For instance, in the period between 26 January and 24 February, 10 issuers placed 10 bond issuances worth a total of $\mathrm{Rb} 45.3 \mathrm{bn}$, the lowest value seen since March 2015 (by comparison, 20 rouble-denominated bond issuances worth $\mathrm{Rb} 97.9 \mathrm{bn}$ were placed in the same earlier period) (Fig. 8). The largest in volume bond issuances were placed by OJSC Norilsk Nickel (a series of exchange-traded bonds worth Rb 15bn) and OJSC Russian Helicopters (a series of exchange-traded bonds worth Rb 10bn)2. Exchangetraded bonds made up nearly half of the bond issuances placed during the period under review. A single mortgage agent managed to raise funds with a maturity of 32 years and six bond issuers raised funds with maturities of 10 years.

Late in January/early February, the Bank of Russia cancelled 10 corporate bond issuances of four issuers (four corporate bond issuances were cancelled on the same grounds in the previous period under review) ${ }^{3}$, in which case the failure to issue bonds was first of all caused by troublesome market conditions.

In the period between 26 January and 24 February, 24 issuers were due to meet their debt obligations worth nearly $\mathrm{Rb} 180 \mathrm{bn}$. However, a single issuer - LLC SU-155 Capital - filed a technical default on three bond issuances (all bond issuers met their debt obligations in the recent few months). Thirteen corporate bond issuances worth a total of $\mathrm{Rb} 66.8 \mathrm{bn}$ are due to mature in March $2016^{4}$.

However, the issue of companies defaulting on debt obligations due to their bond holders continued to be challenging. Apart from a few technical defaults on meeting current debt obligations to bond holders, five

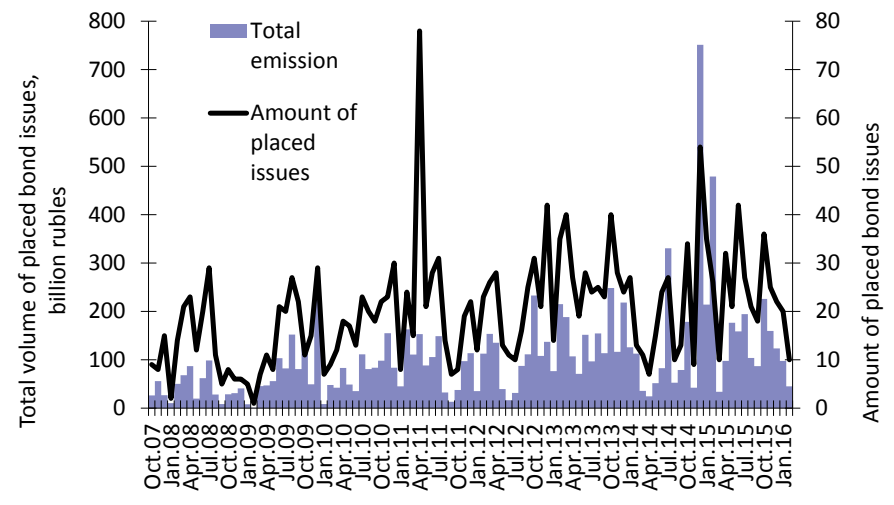

Source: Rusbonds information agency.

Fig. 8. The IPO dynamics of rouble-denominated corporate bonds

1 Based on the data released by Rusbonds Information Agency.

2 Based on the data released by Rusbonds Information Agency.

3 Based on the data released by the Bank of Russia.

4 Based on the data released by Rusbonds Information Agency. 
issuers from various industries were declared in actual default (that is, when an obligor is unable to repay to bondholders even during the grace period) on paying the coupon yield and on the put date (a fairly large number of technical and actual defaults on various types of debt obligations were declared in the same prior period) ${ }^{1}$.

Finally, it is worth noting that some changes may soon take place in the Russian bond market. First, it has transpired that The Housing Mortgage Finance Agency (HMFA) is set to introduce a new financial instrument - nontranche mortgage bonds - in the market. Second, the Russian government mulls over issuing bonds that are pegged to the shares of privatized companies, that is, the redemption amount of such bonds is pegged to the future value of issuer's shares.

1 Based on the data released by Rusbonds Information Agency. 